\title{
Confidentiality and the implementation of the decisions of the African Commission on Human and Peoples' Rights
}

\author{
Rachel Murray* \\ Professor of International Human Rights Law; Director of the Human Rights \\ Implementation Centre, University of Bristol Law School, United Kingdom \\ https://orcid.org/0000-0003-4077-9381
}

\section{Summary}

The African Commission on Human and Peoples' Rights has been criticised for its restrictive application of article 59 of the African Charter on Human and Peoples' Rights resulting, it is argued, in a shroud of secrecy around the protective elements of its work. This article explores the application of the principles and presumptions in article 59 and the confidentiality covering the communication procedure of the African Commission after the adoption of the decision. Research reveals that there may be a greater likelihood of implementation of the recommendations in the decision if it visible and a variety of actors are made aware of its existence and these measures that the state then takes, or fails to take. Drawing upon an Economic and Social Research Council-funded project, the article argues that article 59 in practice has so far been applied without a great deal of thought, to procedures post-decision that monitor the implementation of the recommendations. Thus, at present the African Commission has slipped into presuming that measures taken by the state to implement recommendations, evidence presented by the complainants (or indeed other actors) on the extent to which it has done so, and the Commission's own assessment, fall within the communication procedure and, therefore, by default are confidential. Yet, article 59 does not require this, neither do the Rules of Procedure, and a blanket approach to confidentiality postdecision is not appropriate. The article recommends that the African Commission can improve publication and visibility of the decision itself;

LLB (Leicester) LLM (Bristol) PhD (W England); Rachel.Murray@bristol.ac.uk. I would like to thank Frans Viljoen, Debra Long and Clara Sandoval-Villalba for their helpful and insightful comments on earlier drafts of this article. 
and should be making available on its website and in documentation information on what measures the state has taken to implement the decision.

Key words: Africa; human rights; confidentiality; implementation; article 59

\section{Introduction}

The African Commission on Human and Peoples' Rights (African Commission) has been criticised for its restrictive application of article 59 of the African Charter on Human and Peoples' Rights (African Charter) resulting, it is argued, in a shroud of secrecy around the protective elements of its work. ${ }^{1}$ This article explores the application of the principles and presumptions in article 59 and the confidentiality covering the communication procedure of the African Commission after the adoption of the decision. Research reveals that there may be a greater likelihood of implementation of the recommendations in the decision if it is visible and a variety of actors are made aware of its existence and the measures to implement it that the state then takes or fails to take. ${ }^{2}$ Drawing upon an Economic and Social Research Council (ESRC)-funded project, ${ }^{3}$ I argue that article 59 in practice has so far been applied, without a great deal of thought to procedures post-decision that monitor the implementation of the recommendations.

Since its establishment in 1987 the African Commission has received more than 500 communications under article 55 of the African Charter whereby individuals, civil society organisations (CSOs) and others have submitted cases that allege violations of the rights in the Charter. If admissible, the African Commission then will proceed to look at the merits and, if violations are found, will make 'recommendations' to the state on what action it should take to

1 See eg M Killander 'Confidentiality versus publicity: Interpreting article 59 of the African Charter on Human and Peoples' Rights' (2006) 6 African Human Rights Law Journal 574-575.

2 See eg Open Society Justice Initiative From rights to remedies: Structures and strategies for implementing international human rights decisions (2013).

3 See Human Rights Implementation Project (Project), http://www.bristol.ac.uk/law/ hrlip/ (accessed 1 April 2019). This project tracked the implementation of decisions from nine states: three in Africa (Burkina Faso, Cameroon and Zambia); three in Europe (Belgium, the Czech Republic and Georgia) and three in the Americas (Canada, Colombia and Guatemala), adopted by UN treaty bodies and the regional human rights commissions and courts. It consisted of documentary analyses, in-country workshops, and over 200 interviews with members and representatives of these supranational bodies, and within the nine states, the government representatives, victims, parliamentarians, the judiciary, civil society organisations and academics. Interviews are anonymous. However, where appropriate, information is given on the profile or location of the interviewee. For further information on our methodology, see Journal of Human Rights Practice, Special Issue, 2019, forthcoming. 
remedy those violations. This latter section is found at the end of the decision. These recommendations have varied in number, breadth, detail and sophistication, from a bland 'take measures to comply with its international obligations', to lists of tasks that the state should carry out, such as establishing commissions of inquiry, releasing the individuals, paying compensation and amending legislation. ${ }^{4}$ While the content may still be criticised for their ambiguity, the trend is to become increasingly detailed and focused in setting out what the state should do once violations have been found. Normally the state will be given 180 days to respond to the Commission on the measures it has taken to implement the recommendations. ${ }^{5}$ However, often little is known about whether states in fact implement these recommendations. Systematic follow-up by the African Commission has not yet occurred although ad hoc information is available. ${ }^{6}$ Some of this information is public (for example in its annual reports, or through statements by CSOs), some of it is private, but there does not appear to be a consistent approach or policy on which aspects, if any, should be confidential.

The decision on the communication, including the recommendations that the state should take to address the violations, used to be published in the Commission's Activity Report, but since the African Union (AU) organs restricted the number of pages in 2011,7 the text of the communication now appears under the relevant page on the website.

Article 59 of the African Charter provides:

1 All measures taken within the provisions of the present Chapter shall remain confidential until the Assembly of Heads of State and Government shall otherwise decide.

2 However, the report shall be published by the Chairman of the Commission upon the decision of the Assembly of Heads of State and Government.

3 The report on the activities of the Commission shall be published by its Chairman after it has been considered by the Assembly of Heads of State and Government.

Thus, prior to this approval by the Assembly the decision remains confidential. While the focus of discussion around article 59 principally has been on when decisions and information on them should be

4 See eg G Bekker 'The African Commission on Human and Peoples' Rights and remedies for human rights violations' (2013) 13 Human Rights Law Review 499; R Murray The African Charter on Human and Peoples' Rights. A commentary (2019) ch 2.

5 Rule 112(2), Rules of Procedure of the African Commission on Human and Peoples' Rights, 2010.

6 Eg in its annual reports and in an oral report by the Chairperson of the Working Group on Communications to each ordinary session of the African Commission; see further below.

7 30th Activity Report of the African Commission on Human and Peoples' Rights, 2011. 
published, no debate has taken place on what happens post-adoption of the decision by the African Commission and the AU. One might consider this lack to be irrelevant: Article 59 applies only to the decision pre-authorisation by the $\mathrm{AU}$ organs. However, the policy of confidentiality applicable to its communication procedure risks being applied, by default, to the processes that occur post-decision. Leaving aside cogent criticisms directed at the manner in which article 59 has been employed by the African Commission pre-decision (particularly given interference by the $\mathrm{AU}$ political organs in the content of the Commission's findings), ${ }^{8}$ this restrictive approach does not need to and, indeed, should not automatically apply to any process postadoption of the decision.

There are various points post-decision to which confidentiality may apply, as will be seen below, including information provided by the state on the measures it has taken to implement the decision or judgment; information provided by other actors, including the victims or complainants, on what the state has done, if anything; and the assessment the African Commission may make as to whether those measures are sufficient. These points will be examined in turn.

The African Court on Human and Peoples' Rights (African Court) does not operate under the constraints of article 59. However, given the nascent processes and the potential fluidity of any monitoring mechanism by the African Commission as well as the relationship of both organs with the AU political bodies, this article will draw as well upon the approach of the African Court.

\section{Confidential from whom}

The Oxford English dictionary defines 'confidential' as 'intended to be kept secret', but neither article 59 nor the Rules of Procedure of the African Commission assist in clarifying confidential in relation to whom. Whilst submissions and pleadings during the consideration of a communication are shared by the Commission with the parties to the case, the actual decision on the merits is only provided to the parties after it has been approved by the Assembly of the AU. Thus, 'confidential' in the context of article 59 means different things at different stages of the process: While the case is pending, documents should not be disseminated beyond the parties and Commission, but once the decision has been adopted by the Commission it is not disclosed even to the parties until it has been approved by the Assembly.

The focus of the article is about what happens subsequently, whether the measures taken by the state to implement the decision or judgment are then made public, that is, visible to the parties to the

8 Eg Decision on the 17th Annual Activity Report of the African Commission on Human and Peoples' Rights, Assembly/AU/Dec.49(III); Killander (n 1) 574-575. 
case and the African Commission and beyond, to other stakeholders and the public. At the very least, one would expect the victims to know what action the state has taken in response to the decision, particularly individual measures. The victims themselves have a right to know what the state is doing to redress the violations that occurred. One could argue that this has already been achieved if the state has reported its activities to the victims directly or to them through the treaty or monitoring body. Yet, while the state authorities may engage the victim with respect to any individual measures (such as payment of compensation), the project also obtained evidence in at least one case, that the victim did not know whether other reparations such as guarantees of non-repetition had been implemented. ${ }^{9}$

Consequently, throughout the article I talk of confidentiality in terms of information being made public, beyond the parties to the communication and the treaty body itself.

\section{Other regional systems and the United Nations}

Comparisons with other regional systems reveal a mixed picture.

Under the Council of Europe, as noted below, discussions on what measures the state will take to implement the judgment of the European Court of Human Rights take place in private and without the victim's presence. However, these measures, including their action plans, subsequently are published by the Committee of Ministers, along with submissions from the parties as well as non-governmental organisations (NGOs) and national human rights institutions. ${ }^{10}$ When the Committee decides no longer to supervise implementation it will adopt a resolution. All of these documents are available on-line. ${ }^{11}$ The Parliamentary Assembly's Committee on Legal Affairs and Human Rights also adopts reports on the implementation of judgments. ${ }^{12}$

9 Interview A.7, December 2017.

10 Rules of the Committee of Ministers for the supervision of judgments and of the terms of friendly settlements (adopted by the Committee of Ministers on 10 May 2006 at its 964th session), Appendix 4, item 4.4, Doc CMRules (2006) App 4, Rules 8.2-8.5.

11 See https://www.coe.int/t/dghl/monitoring/execution/Reports/pendingCases_en. asp; http://www.coe.int/en/web/execution/submissions; http://www.coe.int/en/ web/execution/closed-cases (accessed 1 April 2019); also through HUDOC.

12 See eg Committee on Legal Affairs and Human Rights, Implementation of Judgments of the European Court of Human Rights, Report (Rapporteur: Mr Klaas de Vries, The Netherlands, Socialist Group), Doc 13864, 9 September 2015, http:/ /assembly.coe.int/nw/xml/XRef/Xref-DocDetails-EN.asp?FileID=22005\&lang=EN (accessed 1 April 2019). The report forms the basis on which the Parliamentary Assembly adopted Resolution 2075 (2015), http://assembly.coe.int/nw/xml/XRef/ Xref-DocDetails-EN.asp?FileID=22197\&lang=EN and Recommendation 2079 (2015), http://assembly.coe.int/nw/xml/XRef/Xref-DocDetails-EN.asp?FileID=2219 8\&lang=EN (accessed 1 April 2019). 
With respect to cases before the Inter-American Commission for those states that have not accepted the Inter-American Court's jurisdiction the process is confidential. The Commission will consider whether the state has taken adequate measures to comply with its recommendations and, if it has failed to do so, after a vote of an absolute majority of the Commission's members the report on the merits will become public, although in practice all the specific documents submitted by the parties will not. ${ }^{13}$ Where the state has accepted the Court's jurisdiction, if the Commission considers that the state has complied with its recommendations, it can choose whether to publish the report on the merits. ${ }^{14}$ The Inter-American Commission on Human Rights includes sections in its annual reports that set out the action that states have taken and the current state of implementation, separating out friendly settlements from recommendations. ${ }^{15}$ The Commission also could host private working meetings on compliance or thematic hearings (that are not based on a single case) to look at compliance issues.

After the Inter-American Court on Human Rights has issued a judgment it establishes modalities of compliance to be followed by the state that include, for example, when to report to the Court. When the Court receives the state's report it is shared with the legal representatives of the victims for their comments. The report is then sent to the Commission for it also to comment. This entire process is confidential. The Court also can hold private or public hearings to learn more about compliance, but the greatest majority of hearings have been of a private nature.

All the UN treaty bodies consider communications in closed sessions so that the oral deliberations and summary records remain confidential. $^{16}$ Once views on the communication have been formulated it is standard practice for these to be sent to the individual and the state party concerned. ${ }^{17}$ The text of any final decision on the merits of the case or of a decision of inadmissibility is posted on the website of the Office of the High Commissioner for Human Rights (OHCHR) as part of the treaty bodies' jurisprudence. The UN treaty bodies also include information on follow-up in their annual reports to

13 Art 51(3).

14 IACHR Impact of the Friendly Settlement Procedure Doc OEA/Ser.L/V/II.Doc. 45/13, 18 December 2013 para 62, http://www.oas.org/en/iachr/friendly_settlements/ docs/ReportFriendlySettlement.pdf (accessed 1 April 2019).

15 See IACHR, Annual Report 2015, ch II.D, Status of compliance with the recommendations of the IACHR.

16 Eg Human Rights Committee: see art 5(3) of the Optional Protocol to ICCPR and Rule 102(1) of the Rules of Procedure. See also Guidelines on Making Oral Comments Concerning Communications, CCPR/C/159, 21 December 2017 para 3(e).

17 See art 5 of the Optional Protocol to ICCPR, and Rule 101 of the Rules of Procedure of the HRC; Rule 107 of the Rules of Procedure for the CAT; Rule 76 for the Rules of Procedure for CRPD; Rule 29 for the Rules of Procedure for CRC; Rule 74 of the Rules of Procedure for CEDAW; Rule 80 for the Rules of Procedure of CED; and Rule 25 of the Rules of Procedure of ICESCR. 
the General Assembly ${ }^{18}$ or, in the case of the Human Rights Committee (HRC), under the International Covenant on Civil and Political Rights (ICCPR) in the follow-up reports. However, it can be difficult to find specific information on the activities of the Special Rapporteurs on follow-up, whose reports to the respective Committees are noted in the annual report but not necessarily annexed, presumably due to restrictions imposed on the length of the treaty bodies' reports. Furthermore, although the HRC, for example, categorises the response of the state with respect to the implementation of specific recommendations it is not always apparent on which basis this 'grade' is made.

\section{Publicity and implementation}

Why should the measures taken by states to implement these decisions and judgments be made public? First, this requirement is part of the right to truth, not only for the victims in the case but also for the wider public. ${ }^{19}$

In addition, research around why and how states implement decisions and judgments from human rights treaty bodies and indeed international legal courts and tribunals identifies a range of factors with different theories attempting to explain the rationale behind states' responses. $^{20}$ Some argue that if one can 'generate publicity about compliance patterns [one can] ... raise awareness among

18 See HRC General Comment 33 para17.

19 UN Human Rights Council, Right to Truth, A/HRC/RES/9/11; UN Working Group on Enforced or Involuntary Disappearances, General Comment on the Right to the Truth in Relation to Enforced Disappearances, A/HRC/16/48. See eg Dino Noca $v$ Democratic Republic of the Congo Communication 286 2004, para 158; Bekker (n 4$)$ 499. See also before the European Court, El-Masri v Former Yugoslav Republic of Macedonia App 39630/09 para 191; UN Human Rights Council, Right to Truth, A/HRC/RES/9/11. The Aire Centre, Amnesty International, IC), OMCT, Redress, Joint NGO Response to the Standing Committee on the Rules of Court's Report on the Treatment of Classified Documents, Al Index: IOR 60/8245/2018, 5 April 2018.

20 F Viljoen \& L Louw 'State compliance with the recommendations of the African Commission on Human and Peoples' Rights, 1994-2004' (2007) 101 American Journal of International Law 1; F Viljoen \& L Louw 'The status of the findings of the African Commission: From moral persuasion to legal obligation' (2004) 44 Journal of African Law 1; Open Society Justice Initiative (n 2); Open Society Justice Initiative From judgment to justice. Implementing international and regional human rights decisions (2010); R Murray \& D Long Implementation of the findings of the African Commission on Human and Peoples' Rights (2015); B Çalı \& A Wyss 'Why do democracies comply with human rights judgments? A comparative analysis of the UK, Ireland and Germany, 26 August 2009; D Hawkins \& W Jacoby 'Partial compliance: A comparison of the European and Inter-American Courts of Human Rights' (2010) 6 Journal of International Law and International Relations 35 40; C Hillebrecht 'Rethinking compliance: The challenges and prospects of measuring compliance with international human rights tribunals' (2009) 1 Journal of Human Rights Practice 368; C Hillebrecht Domestic politics and international human rights tribunals: The problem of compliance (2014); F Viljoen 'Exploring the theory and practice of the relationship between international human rights law and domestic actors' (2009) 22 Leiden Journal of International Law 177. 
agencies and ... make it easier for the media to follow up on problem areas'. $^{21}$ As the Open Society Justice Initiative (OSJI) report made clear: 'Improving the visibility, accessibility, and accuracy of information pertinent to implementation is also essential. ${ }^{22}$

The project found that there is a distinction but inter-relationship here with the awareness of the treaty body issuing the decision, awareness of the decision itself and the visibility of the measures taken by the state to implement any of the reparations contained therein. Thus, there was some evidence from the cases that were examined that, tied up with the implementation is a lack of awareness of the treaty bodies: 'Most government officials don't know there is an African Commission on Human and Peoples' Rights. Very, very few people. Even lawyers don't know there is an African Commission. ${ }^{23}$ Consequently, there may be little knowledge among citizens and lawyers about the existence of these communication procedures and how they operate, ${ }^{24}$ and government officials may not have regular engagement with the African Commission through, for instance, attendance at its sessions. ${ }^{25}$ This lack of knowledge may be related to,

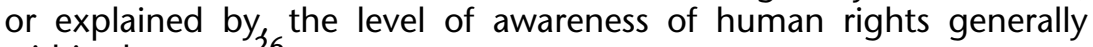
within the state: 26

The problem of implementation of decisions of international bodies ... is really a symptom of a root cause ... the human rights culture in the country, but also the level of awareness among the citizens, but, possibly very importantly among the officials.

With respect to the decision itself the project heard in some of the cases that the amount of publicity determined whether the state reacted and how quickly, as it could prompt key domestic actors to ask questions of the executive. ${ }^{27}$ Conversely, where the decision is not known this 'reduces the possibility of intense pressure from citizens. Popular pressure is missing ... I see lack of ownership of these

21 V Gauri, J Staton \& JV Cullell 'A monitoring mechanism for constitutional decisions on the Costa Rican Supreme Court' 2012 International Congress of the Latin American Studies Association (21 May 2012) 5, cited in Open Society Justice Initiative (n 20) 100. Report of the Human Rights Committee, UN Doc A/51/40 paras 435-438; then in Rules of Procedure 2012, Rule 103.

22 Open Society Justice Initiative (n 20) 29.

23 Interview with civil society representative, Cameroon, March 2017. Round Table on Factors Influencing the Implementation of Decisions of Human Rights Bodies, Yaoundé, Cameroon, 5 July 2017 (on file with author).

24 Eg HRLIP Evaluation by Burkina Faso of their implementation of decisions made by international human rights bodies, Ouagadougou, 27-28 November 2017, Workshop Report; Interview with government official, 20 March 2018.

25 General Report of the Regional Seminar on the Implementation of Decisions of the African Commission on Human and Peoples' Rights, 12-15 August 2017, Dakar, Senegal. F Viljoen \& C Odinkalu The prohibition of torture and ill-treatment in the African human rights system: A handbook for victims and their advocates OMCT Handbook Series Vol 3, OMCT, Geneva, Switzerland, 2014.

26 Interview with civil society representative, Zambia, March 2017. See also General Report (n 25); Interview A3, December 2017.

27 Eg interview with parliamentarian, Zambia, August 2017. 
decisions ... The problem is not because people are not willing but that they are unaware. ${ }^{28}$

States may be more likely to respond if the decision is more visible and may take a pragmatic approach accordingly. As one government official acknowledged in the project: 'It's about which one gets more publicity, and so then that determines also how much attention is given to it ... sometimes the speed at which a matter moves is very dependent on what attention is gotten. ${ }^{29}$

Here visibility is relevant not just at the national level but also regionally and internationally: 'A country agrees to implement ... international decisions depending on how it sees or views the human rights at the global level ... [the country] must make progress at continental and global levels in terms of human rights. ${ }^{30}$

Furthermore, the legitimacy of the treaty body itself, according to some, may also be at stake. One rationale for a body such as the African Commission to publish information on the measures taken by the state to implement the decision is that it shows that it is doing something to monitor the situation and, as one litigant said, 'that someone is keeping track'.31 Consequently, without such transparency there is a risk that any decisions that are taken may be tainted by political interference. ${ }^{32}$

Without a systematic recording of the measures taken by states to implement the recommendations of the African Commission one has a skewed picture of the extent of implementation. As two interviewees told us: 'We tend to only hear about cases where the complainant has not received any compensation'; 33 and that 'states sometimes do good things but not able to tell us' $^{\prime}{ }^{34}$ Furthermore, this situation can result in 'rumours' around what did or did not happen in response to the decision and lack of concrete evidence. ${ }^{35}$

While there are strong arguments for information post-decision to be public a blanket approach may not always be wise. There may be cogent reasons why some issues should be kept confidential. First, it may be necessary to protect individuals and their identities, particularly if the victim has been the subject of criminal proceedings at the national level. Second, and this argument relates to the fact that there can be limited knowledge at the national level of the work of the treaty body, the project heard concerns from one state that if

28 Interview with government official, Burkina Faso, December 2017.

29 Interview Zambia, March 2018. Interview with civil society organisation, Zambia, March 2017.

30 Interview with civil society organisation, Burkina Faso, December 2017.

31 Interview D11, May 2017.

32 CA Odinkalu 'The individual complaints procedures of the African Commission on Human and Peoples' Rights: A preliminary assessment' (1998) 8 Transnational Law and Contemporary Problems 359 fn 49.

33 Interview with civil society representative, Burkina Faso, July 2017.

34 Interview B2, July 2017.

35 Interview with civil society representative, Burkina Faso, July 2017. 
the public knew, for example, that compensation had been paid to particular individuals, this would open a 'Pandora's box' for others to claim, and that some discussions are best dealt with through a 'process of quiet negotiation'. ${ }^{36}$

Third, in some circumstances it may engender trust between the African Commission and the state if it is able to report difficulties to it in confidence, views echoed by a litigant, as well as a member of the Commission: ${ }^{37}$

You want the parties to report to you the challenges they are facing without feeling like they are exposed to the public. We need the state to be able to come to you openly and have that protection there. If you get the feeling that this will be out there and exposed ... it is similar to the amicable settlement procedure.

States also may be reluctant to make the actual decisions public when compared anecdotally with the recommendations in the Universal Periodic Review (UPR). As one state representative told us, in part because of the language involved, the audience to whom it is directed, and the apparent discretion the state has in terms of how it addresses the recommendation: ${ }^{38}$

The state decides whether to accept recommendations and so tries to inform the entire international community on the decision. Individual communications always have words condemning states. The UPR procedure is much more diplomatic and encouraging and facilitating, as compared with individual communications. So it incentivises the state and raises awareness of other people in informing them what is being done.

In conclusion, this finding does not lead us to suggest that confidentiality should apply to all such instances, but what it does point to is a need for greater clarity on when and what should be made public.

\section{Relevant elements of the process}

There are a number of different elements of the communication procedure post-decision that need to be considered.

\subsection{Provisional measures}

The African Commission can issue provisional measures according to Rule 98 of its 2010 Rules of Procedure (and former Rule 111 of its 1995 Rules) and has done so in a number of cases. ${ }^{39} \mathrm{~A}$

\footnotetext{
36 Interview C1, March 2017.

37 Interview D8, May 2017; interview D2, April 2017.

38 Interview, February 2018. See also Round Table on Factors Influencing the Implementation of Decisions of Human Rights Bodies, Yaoundé, Cameroon, 5 July 2017 (on file with author).

39 For a discussion, see CB Herrera \& F Viljoen 'Danger and fear in prison. Protecting the most vulnerable persons in Africa and the Americas by regional human rights
} 
communication must be pending before the Commission before it will consider provisional measures. ${ }^{40}$ The challenge arises in that if the communication is pending, any issue relating to it, including provisional measures, then, according to the African Commission, will be considered confidential. In fact, on no occasion have provisional measures adopted by the Commission been made public. All that is available is a brief mention in the activity report of the Commission citing the name of the case ${ }^{41}$ and, again usually in passing, reference in the decision on the communication that provisional measures were requested and accepted or rejected by the African Commission. ${ }^{42}$ There is no separate 'decision', and it is not clear if the Commission's conclusions on granting provisional measures are a separate 'order' (as it has referred to it in some communications) ${ }^{43}$ or merely a procedural element of the communication mechanisms in the same way as, say, seizure.

Rule 98 refers to the provisional measures being a 'request' taken by the African Commission (or the Chairperson or Vice-Chairperson if the Commission is not in session). ${ }^{44}$ This request is sent to the state party and then only is it forwarded to the victim, the Assembly, Peace and Security Council (PSC) and the AU Commission. ${ }^{45}$ In this regard, therefore, it does not appear to warrant authorisation by the Assembly, in contrast to a final decision on the merits under article 55 of the African Charter. Yet, this possibility could contradict article 59(1) which provides that '[a]II measures taken within the provisions of the present Chapter shall remain confidential until the Assembly of Heads of State and Government shall otherwise decide', the Chapter being articles 46-59, but not article 45. The reference to 'all measures' seems unequivocal. Yet, while the African Commission has called on parties not to disseminate information, in practice it is not clear how consistently it has done so and there is evidence that this request has been disregarded. ${ }^{46}$ The result of this confused state of affairs, as Herrera and Viljoen note, is that '[i]t is virtually impossible to establish exactly how many [provisional measures] have been adopted by the ACHPR and whether the state concerned complied with the request'. ${ }^{47}$ Under its Rule $118(2)$, the African Commission can refer to

bodies through interim measures' (2015) 33 Netherlands Quarterly of Human Rights 163.

40 'At any time after the receipt of a Communication and before a determination on the merits', Rule 98(1), Rules of Procedure of the African Commission, 2010.

41 Eg, 44th Activity Report of the African Commission on Human and Peoples' Rights para 21.

42 Herrera \& Viljoen (n 39) 170-171.

43 Eg, Ahmed Ismael \& 528 Others $v$ the Arab Republic of Egypt Communication 467/ 14, 27 May 2016; The Indigenous Peoples of the Lower Omo (represented by Survival International Charitable Trust) v Ethiopia Communication 419/12, 35th Activity Report of the African Commission on Human and Peoples' Rights para 27.

44 Rule 98(2), Rules of Procedure of the African Commission, 2010.

45 Rule 98(3), Rules of Procedure of the African Commission, 2010.

46 Information on file with author.

47 Herrera \& Viljoen (n 39) 191. 
the African Court any communication where a request for provisional measures has not been complied with.

Before the African Court the order on provisional measures is made public. $^{48}$

\subsection{Proceedings to determine reparations and the reasoning in the decision}

Before the African Commission there is no separate procedure, written or oral, to determine the recommendations or reparations that the Commission makes in the finding of a violation. Instead, these issues are dealt with as part of the written submissions in the communication and in any hearings, both of which are governed by article 59 and, therefore, confidential. ${ }^{49}$ Before the African Court, while the pleadings when the case is pending before the Court are confidential, ${ }^{50}$ the Court's Rules enable additional submissions on reparations, post-judgment, and the issuing of a separate ruling on reparations. ${ }^{51}$ While the pleadings in this second process, on the reparations, also are private, the ruling itself will be public.

Furthermore, in part because before the African Commission reparations are dealt with in the merits, the reasoning provided in the decision on how the Commission reached its recommendations often is limited if not absent. This practice is not without consequence because, as the project found for one state, it can impact on the legitimacy of the Commission and how it is perceived. ${ }^{52}$

\subsection{Publication and visibility of the actual decision}

The decision on the communication, which includes recommendations that the state has to implement to remedy the violations, is adopted by the African Commission at one of its sessions. It is then submitted to the AU organs in accordance with article 59 and, usually, approved. ${ }^{53}$ It is only after its publication has been authorised by the AU Assembly at its Summit that the decision on the communication becomes public. 54

48 Eg App 016/2017, Dexter Eddie Johnson v Republic of Ghana, Order for Provisional Measures, 28 September 2017.

49 Rule 110(2), (3) and (4) (decision on the merits): 'The Commission shall deliberate on Communications in private, and all aspects of the discussions shall be confidential.'

50 Interview D5, May 2017.

51 Eg App 004/2013, Lohe Issa Konaté v Burkina Faso, Judgment on the merits, 5 December 2014; Ruling on Reparations, 3 June 2016.

52 Eg Interview B7, 28 February 2018.

53 However, see for instances where this has not occurred, Decision on the Activity Report of the African Commission on Human and Peoples' Rights (ACHPR), EX CL/ Dec310 (IX); F Viljoen International human rights law in Africa (2007) 199; R Murray Commentary on the African Charter on Human and Peoples' Rights (2019) ch 36.

54 See eg Decision on the 44th Activity Report of the African Commission on Human and Peoples' Rights, EX CL/Dec 1014 (XXXIII) para 1. 
The broad applicability of article 59 to the whole communication procedure has been critiqued. ${ }^{55}$ This situation is not helped by the fact that the some versions of the African Charter, including the version for some time published on the website of the African Commission itself, stated under article 59 that '[a]॥ measures taken within the provisions of the present Charter shall remain confidential until the Assembly of Heads of State and Government shall otherwise decide', with 'Charter' being inserted instead of 'Chapter'. This confusion may explain, in part, the very limiting interpretation of the scope of article 59 by the African Commission.

Prior to the adoption of the decision, the applicability of article 59 is strict. This ruling is buttressed by the Rules of Procedure of the African Commission. Rule 18(d) requires that its Secretary will 'ensure confidentiality of the Commission's records where appropriate', and the staff similarly have obligations to 'observe the principle of confidentiality in all matters that the Commission considers confidential as stipulated under the Charter and these Rules'.56 Communications are discussed in private sessions and Rule 31 notes that 'deliberations shall remain confidential', with the Commission ensuring the 'confidentiality of all case files, including pleadings'.57 Although the Chairperson of the Commission 'may communicate to the public general information on deliberations in private sessions', this possibility is 'subject to the exigencies of article 59 of the Charter and any special directions by the Commission'. In practice it has meant that the only information revealed while a communication is pending in the Commission's activity report is the name and number of the communication and at what stage it is at in the Commission's deliberations. ${ }^{58}$ Consequently, pleadings and submissions by the parties on pending communications are considered confidential, and the African Commission has called on parties not to publish their submissions on their websites. 59

Rules 110(2), (3) and (4) of the 2010 Rules of Procedure provide that the decision will remain confidential even after having been signed by the Chairperson and Secretary of the African Commission and will be transmitted to the parties only once the Assembly has authorised its publication. The Rules also require the African Commission to then post the decision on its website. ${ }^{60}$

55 Eg Killander (n 1) 572.

56 Rule 22 African Commission Rules of Procedure.

57 Rules 31(1) and (3) respectively, Rules of Procedure of the African Commission 2010.

58 Eg 44th Activity Report of the African Commission on Human and Peoples' Rights Submitted in Accordance with Article 54 of the African Charter on Human and Peoples' Rights, November 2017-May 2018 para 21.

59 Information on file with author.

60 See also Rule 18(i) (functions of the secretary): 'Make available to the general public documents which are not confidential, including states reports, by ensuring that they are posted on the website of the Commission.' 
The first matter relevant to the implementation of the decision is the extent to which the decision itself is visible and publicised. Once the decision is made public, it may not be visible and may reach few people beyond the actual parties to the communication, a situation acknowledged by the African Commission itself. ${ }^{61}$ While the African Court specifically has required the state to place a summary of the judgment in its official Gazette, a 'widely-read' national daily newspaper and on the official website for one year, ${ }^{62}$ the African Commission has not adopted a similar approach. Consequently, and in light of the lack of awareness of the work of the Commission generally at the national level, in the states involved in the project certainly, the decision easily can disappear from sight.

The requirement that it is only the parties with whom the African Commission will communicate while the matter is pending before it spills out beyond the decision itself. While the Commission places the decision on its website, the presumption appears to be that those wishing for more information, such as national human rights institutions or civil society organisations in the state, are encouraged to approach the Commission, rather than the Commission having an obligation to disseminate the decision itself. As noted in the report of the Working Group on Communications, '[o]nce the Activity Report of the Commission has been authorised for publication by the AU policy organs, the general public can have access to the text of the decisions referenced in that report'.63

The practical difficulty is how the 'general public' can get access to such texts or even are aware of their existence. This is exacerbated by the fact that the website of the African Commission is not always updated, links are broken, and decisions, even after their adoption, can disappear from the site if they were ever put there in the first place.

Consequently, even though there is no question over the extent to which the decision itself should be published, in reality publication does not equate with visibility.

While national stakeholders, including parliament, may be waiting for the state authorities to share information with them, the project was also informed that the executive may not see it as within its role to do so, nor did they see the need to inform others outside of government. As one ministry official from Cameroon told us, 'it is not our authority to inform the public ... [we] inform the people with the ... objective to implement the decision. It is not for us to inform

61 See General Report (n 25) para 23.

62 See eg Lohe Issa Konaté v Burkina Faso App 004/2013, Judgment on Reparations, 3 June 2016 para 60(viii).

63 Report of the Chairperson of the Working Group on Communications, by Commissioner Lucy Asuagbor, presented during the 56th ordinary session of the African Commission on Human and Peoples' Rights, Banjul, The Gambia, 21 April7 May 2015 para 15. 
people or parliament. ${ }^{64}$ Consequently, perhaps the communication is seen simply to 'focus on people involved in order to resolve the problem' rather than seeing it as information for others, 'the communication is not talking to the entire population but to the people concerned'. ${ }^{65}$

\subsection{Process within the state determining how the recommendations are to be implemented}

The implementation of decisions will require a range of different procedures and processes to be initiated, through executive departments, the courts or parliament. Whether the state has appointed a particular ministry or department to coordinate the implementation varies from state to state and from decision to decision. In the three countries in Africa involved in the project, for instance, one had an inter-ministerial committee to coordinate the government response (Cameroon), the others had ad hoc mechanisms (Burkina Faso and Zambia) and all three countries required additional procedures to be followed to ensure the implementation of specific aspects of the recommendations. The state may also need to discuss the technicalities of implementation with the African Commission itself, although in the cases the project examined this possibility does not appear to have been utilised.

There will inevitably be a need for the government to discuss internally how it will coordinate and manage this process of implementation. Depending on where this takes place, the extent to which these discussions are, and should be, transparent is important to consider. In Cameroon, discussions on implementation take place in the Inter-Ministerial Committee for Monitoring the Implementation of Recommendations and/or Decisions Arising from International and Regional Mechanisms for the Promotion and Protection of Human Rights and, while the Committee has a broad composition, it meets erratically and its findings are not made public. ${ }^{66}$

\subsection{Assessment by the African Commission of the measures taken by the state}

Rule 112 provides for the procedure on 'follow-up on the recommendations of the Commission' and reads:

(1) After the consideration of the Commission's Activity Report by the Assembly, the Secretary shall notify the parties within thirty (30) days that they may disseminate the decision.

64 Round Table on Factors Influencing the Implementation of Decisions of Human Rights Bodies, Yaoundé, Cameroon, 5 July 2017 (on file with author).

65 As above.

66 As above. See also interview B5, 26 February 2018; interview B8, 28 February 2018. 
(2) In the event of a decision against a state party, the parties shall inform the Commission in writing, within one hundred and eighty (180) days of being informed of the decision in accordance with paragraph one, of all measures, if any, taken or being taken by the state party to implement the decision of the Commission.

(3) Within ninety (90) days of receipt of the state's written response, the Commission may invite the state concerned to submit further information on the measures it has taken in response to its decision.

(4) If no response is received from the state, the Commission may send a reminder to the state party concerned to submit its information within ninety (90) days from the date of the reminder.

(5) The Rapporteur for the communication, or any other member of the Commission designated for this purpose, shall monitor the measures taken by the state party to give effect to the Commission's recommendations on each communication.

(6) The Rapporteur may make such contacts and take such action as may be appropriate to fulfil his/her assignment including recommendations for further action by the Commission as may be necessary.

(7) At each ordinary session, the Rapporteur shall present the report during the public session on the implementation of the Commission's recommendations.

(8) The Commission shall draw the attention of the Sub-Committee of the Permanent Representatives Committee and the Executive Council on the Implementation of the Decisions of the African Union, to any situations of non-compliance with the Commission's decisions.

(9) The Commission shall include information on any follow-up activities in its Activity Report.

There are various tools that the African Commission has used to collate information on the measures taken by the state to implement its decisions. One needs to consider what aspects of this procedure should be and, indeed, currently are public.

\subsubsection{Information provided by the parties and others on the measures taken by the state to implement the decision}

The project attempted to find what measures the states had taken to implement the decisions. There were challenges in doing so as, in the three African states there is no one place where this information is provided at the national level, nor does the African Commission show this information in an easily-accessible location. Rather, one has to look across statements made by the state representatives at the Commission sessions and reference to these cases and measures in documents adopted by the Commission, including its Concluding Observations or any resolutions it adopted.

The project found that there are a number of reasons why there is a need for the information on the measures taken to implement the decision to be made public. First, this may be one way or indeed the 
only way in which the litigants learn what the state has done. ${ }^{67}$ Additionally, in the interests of justice one would presume that the victims themselves, at the very least, should know what action the state has taken to address their violations. Without a clear policy on what is confidential and what is not, the project found that sometimes even the victims and complainants themselves were not aware of the information that the state had shared with the treaty body, for instance: 'We usually would get copies of any correspondence that was sent, but we have never received anything from the state that said "Listen, here we are. Here's the new law - look, it's fine" or anything of the sort. ${ }^{\prime 68}$

Making public the measures (or lack of measures) taken by states to implement decisions and judgments can mean that examples of good as well as bad practices among states can be identified, and credit can be given to states that have implemented reparations. Moreover, more visibility can enable the accuracy of any information submitted to the supervisory bodies on the measures taken by the state to be verified. If the supervisory body has only one source of information, whether that be from the state itself or from the complainant, it may not be in a position to determine whether that information indeed is reliable. Making those claims public could enable others to come forward with further evidence.

Thus, visibility is another tool to facilitate state accountability, particularly if the information emanating from any national mechanism is not available. As one civil society representative told us in relation to Cameroon, 'the follow up mechanism is the interministerial committee but it is difficult to track, it sits within the PM office and made of many ministries' ${ }^{69}$

Visibility then enhances the capacity of the complainant to bring further awareness to the level of implementation: 'The complainant plays a very big role in making the noise about their issue, and then a bit of attention is given to it. ${ }^{170}$

Hence, if one accepts that there should be visibility of the action taken by the state to implement the decision, then it becomes important to determine how the African Commission makes such information public. At the moment its approach is ad hoc, making incidental references in resolutions, the state reporting procedure and in its activity reports. ${ }^{71}$ There is a strong argument for the African Commission to maintain a database on its website that will display the

67 Eg interview D11, May 2017.

68 As above.

69 Round Table on Factors Influencing the Implementation of Decisions of Human Rights Bodies, Yaoundé, Cameroon, 5 July 2017 (on file with author).

70 Interview with government official, March 2018.

71 See below. 
actions taken by the state as against each of the recommendations in the communication. ${ }^{72}$ However, this demand will require that it has a process and system by which it is able to seek information from various sources beyond the parties to the case, to test its accuracy and to cross-check it against other sources, before making this available on any public-facing database.

Indeed, the project has evidence that the African Commission holds considerably more information on the measures taken by the state to implement the decision, but this has not been made available as a matter of course to those outside the Commission. ${ }^{73}$

\subsubsection{African Commission's monitoring process}

The African Commission does not have a process, as such, to monitor the implementation of its decisions. Rather, beyond sending letters to the parties asking for information on any measures taken it utilises its other procedures to seek information.

The African Commission sometimes asks questions of the state during the article 62 state-reporting process on the measures taken to implement decisions. These questions may be posed in public during that part of the session of the Commission and the state may or may not respond to them at the time, with the manner in which the oral examination takes place enabling them to evade answering certain questions. Consistency and regular contact between the African Commission Rapporteur for the state report and domestic civil society organisations and the national human rights institution could facilitate the asking of more pointed questions during the oral examination. Written responses from the state almost never are made public and while the Concluding Observations adopted by the African Commission are public and increasingly detailed, including some examples where the implementation of decisions have been raised, they are not consistently available on the Commission's website. The few examples of references to implementation of decisions are ad hoc and brief. A low-resource approach that would maximise the potential for the state-reporting process to assist here is to require that Concluding Observations have a standard paragraph that requires the state to report back on the implementation of decisions.

In addition to state reporting, a handful of resolutions adopted by the African Commission in relation to particular states have identified the measures taken or failed to have been taken by the authorities in implementing a decision. There are only a small number of instances where resolutions refer to the implementation of decisions, for example, in relation to Gunme \& Others $v$ Cameroon, ${ }^{74}$ where its

72 This was also a recommendation in Dakar: General Report (n 25): 'Develop a database with periodic updates on the status of implementation of decisions by states.'

73 Interview D1, 20 April 2017.

74 AHRLR 9 (ACHPR 2009). 
resolution in 2018 noted ongoing concerns with the situation in the country. ${ }^{75}$ Thus, it is not clear on what basis the Commission will adopt a resolution urging the implementation of a case and why it has done so for these and not for others.

Depending on the timing, the African Commission and its special mechanisms have highlighted specific decisions during their missions to states and referred to evidence obtained in relation to their implementation in subsequent reports. ${ }^{76}$ These reports are not always provided on the Commission's website although it is not clear if this is because they are intended to be confidential or because of a lack of resources at the Secretariat to ensure an up-to-date and comprehensive website.

The African Commission has held hearings on communications, but on two occasions only has it held hearings to examine implementation, one in relation to the Endorois case against Kenya ${ }^{77}$ and one for communications against Mauritania. ${ }^{78}$ They clearly are the exception rather than the rule. Rule 25(2) of the Commission's Rules of Procedure provides that '[s]essions of the Commission shall be held in public unless the Commission decides otherwise or if it appears from the relevant provisions of the Charter that the meeting shall be held in private'.

One may argue that hearings on implementation no longer fall under article 59 as the decision has been authorised by the Assembly and made public. Yet, in practical terms, those who are likely to be aware that the hearing will take place principally are the parties. Communications are slated to be discussed during the private sessions, and one would presume that any hearings on implementation by default would happen then as well.

In addition, there is no clear policy on how the hearings should be run. As one person involved in one of the two hearings that had been held told us, 'the hearings ... are sort of well, appear to be confidential, don't they? Although that's not I guess, clear, 'cause

75 Resolution on the Human Rights Situation in the Republic of Cameroon, ACHPR/ Res 395 (LXII), 9 May 2018. See also, in general, press release on the human rights situation in Cameroon, 29 January 2018, although this does not explicitly reference the decision. See also Resolution Calling on the Republic of Kenya to Implement the Endorois Decision, ACHPR/Res.257, 5 November 2013; see also Resolution on the Protection of Indigenous Peoples' Rights in the Context of the World Heritage Convention and the Designation of Lake Bogoria as a World Heritage site, ACHPR/Res 197, 5 November 2011.

76 Eg listed among the 'positive developments' was Cameroon's implementation of Association of Victims of Post Electoral Violence \& Another $v$ Cameroon (2009) AHRLR 47 (ACHPR 2009) by payment of compensation.

77 See R Martin "'The Endorois decision" - Four years on, the Endorois still await action by the government of Kenya', https://minorityrights.org/2014/09/23/theendorois-decision-four-years-on-the-endorois-still-await-action-by-the-government -of-kenya/ (accessed 23 September 2014).

78 See LM Bingham \& J Harrington 'Never-ending story: The African Commission evolving through practice in Malawi Africa Association et al v Mauritania' (2013) 1 Human Rights and International Legal Discourse 7. 
there's no rules, procedure that cover it. ${ }^{179}$ Consequently, the approach was described to us as 'chaotic' ${ }^{80}$ The decision to hold them in private appears to be by default rather than design.

If the hearings are to be public, the question then arises of when they would be held. The discussion of communications takes place in the private sessions of the African Commission, in the second half of the session and, consequently, when many other state delegates, national human rights institutions and civil society organisations have left. ${ }^{81}$ Although in theory there is no reason why the African Commission could not hold such hearings in public and during its sessions, this will require a change from the normal practice. Holding the hearings during extraordinary sessions that have so far taken a more ad hoc approach to when matters will be public or private may also be a possibility, as may having them separate to the session (or even in the state to which they relate), although to do this inevitably would require additional resources. ${ }^{82}$ Lessons could be learnt from the practice of the African Committee of Experts on the Rights and Welfare of the Child (African Children's Committee). ${ }^{83}$

Hence, consideration needs to be given to the role of the hearing and whether it also is an attempt to come to a settlement ('Let them meet face to face publicly. Try to at least to discussion in the open outstanding issues that really have not been settled'); ${ }^{84}$ to assist in the clarification of what steps the state should take to implement the decision; and/or to obtain information from the parties on what measures have been taken. A decision impacts on who should attend, how it should be organised and where. If, for instance, it is to promote the decision, then holding any hearing in private will not facilitate the involvement of national stakeholders. The experiences of the Inter-American Commission on Human Rights, which can hold working groups in private, hearings in public, and thematic hearings dealing with implementation, could provide a useful model on which the African Commission could draw. ${ }^{85}$

\subsubsection{Criteria to measure implementation}

The African Commission, one presumes in line with its requirement to report on such to the Commission's session and to the AU's Permanent Representatives Committee and Executive Council in Rules $112(7)$ and (8), will need to make some assessment also whether the

79 Interview D1, April 2017.

80 As above.

81 Eg interview D2, April 2017.

82 As above.

83 See eg https://www.chr.up.ac.za/news-archive/505-centre-for-human-rights-takespart-in-african-children-s-rights-committee-hearing-on-implementation (accessed 1 April 2019).

84 Interview D1, April 2017.

85 V Kristicevic 'A strategy for improving the level of implementation of judgments in the Inter-American system' (2010) 16 Interights Bulletin 92-93. 
state has satisfactorily implemented the recommendations in the decision. In order to do so, it must first obtain the information on what the state has actually done. It then must determine the criteria for how it measures implementation ${ }^{86}$ which is not a straightforward process. ${ }^{87}$ On the one hand, determining if an individual has been released from custody, for instance, could appear to be easily fulfilled. However, on the other, if no time frame is given in the decision as to when the individual should be released and the state authorities take time to do so, when will the African Commission consider that it has or has not been satisfactorily implemented? If the recommendations are vague ('comply with its international obligations'), the assessment, in itself, may require the clarification of certain benchmarks. Complex political situations and guarantees of non-repetition raise different challenges. For instance, how precisely does the African Commission evaluate when the Cameroonian government has 'stop[ped] the transfer of accused persons from the Anglophone provinces for trial in the Francophone provinces' ${ }^{88}$

The process and criteria, if it has any, by which the African Commission determines state implementation is not yet apparent. At present there is evidence from the project that even if the state has submitted information it is not clear what the Commission thinks about this. As one litigant told us: 'We submitted a dossier of one thousand pages. Interestingly enough that particular file was lost ... we try our best to make all that information available ... you don't get any feedback ... Nothing. ${ }^{.89}$

Without an indication from the Commission that it has taken these submissions into account in some way there is a risk that further information will not be sent by the parties. As litigants informed us: 'We keep reminding the state, reminding the Commission, but we are leaning to think, of course, that it is a waste of time.' As a result it is reported: 'I don't see them doing a lot, to be honest, on implementation', and 'It never really [followed up on deadlines] and then it never really follows up properly.'

\subsubsection{Working Group on Communications' report on implementation and the African Commission's activity report}

The Working Group on Communications having been given the mandate to monitor the implementation of decisions, ${ }^{90}$ now issues a

86 D Hawkins \& W Jacoby 'Partial compliance: A comparison of the European and Inter-American Courts for Human Rights' (2010) 6 Journal of International Law and International Relations 35.

87 D Long \& A-K Speck 'Measuring implementation' (2019) Journal of Human Rights Practice Special Issue (forthcoming).

88 Gunme (n 74) para 215(2).

89 Interview April 2017.

90 Resolution on the Mandate of the Working Group on Communications of the African Commission on Human and Peoples' Rights, ACHPR/Res 212, 1 March 2012. 
report at every session that can provide a list of cases and provides some brief detail on the status of implementation. For instance, while the report to the 60th session of the African Commission noted some 'constructive dialogue' between the parties and the Commission around the implementation of Communication 318/06 and that there had 'not been a debut of implementation' with respect to four cases, this was all that was provided. ${ }^{91}$ In addition, the African Commission's activity report now includes the odd sentence or two on actions regarding some communications and provisional measures. ${ }^{92}$

This practice is not comparable to the detail provided by the InterAmerican system nor, albeit to a lesser extent, by the African Court. It is not at all clear whether the AU, when the African Commission reports to it, receives any more information than that which is provided at the sessions.

\subsection{Referral to the African Court}

Rule 118(1) of the African Commission's Rules of Procedure enables the Commission if it 'considers that the state has not complied or is unwilling to comply with its recommendations' to submit the communication to the African Court. If the African Commission is to do so, it will have had to gather information on the measures to implement taken by the state. Litigants have been making requests for such referrals. The African Commission, unlike the Inter-American Commission, 93 has not made public any detailed criteria it applies when determining which cases to refer to the Court. So far it has referred only three cases, and none of them on the basis of article 118(1). Conversely, because the process for decision on referral is an internal matter of the African Commission, no detail can be gleaned from the African Court's subsequent judgment as to why the case was referred. ${ }^{94}$

91 Inter-Session Activity Report (November 2016-May 2017) of Hon Commissioner Lucy Asuagbor, Chairperson of the Working Group on Communications, presented at the 60th ordinary session of the African Commission on Human and Peoples' Rights, Niamey, Niger, 8-22 May 2017 paras 29-30.

92 Eg 35th Activity Report of the African Commission, reference to Egyptian Initiative for Personal Rights and Interights v Egypt II (2011) AHRLR 90 (ACHPR 2011), to 'follow-up on implementation', 27; see also para 27: 'With regards to 419/12, The Indigenous Peoples of the Lower Omo (Represented by Survival International Charitable Trust) $v$ Ethiopia, the Commission issued an order against the state, requesting the latter to adopt provisional measures to prevent irreparable harm being caused to the victim of alleged human rights violations; the state has not respected that order.'

93 See Rules of Procedure of the Inter-American Commission on Human Rights Approved by the Commission at its 137 th regular period of sessions, held from 28 October to 13 November 2009, and modified on 2 September 2011 and during the 147th Regular Period of Sessions, held from 8-22 March 2013, for entry into force on 1 August 2013, art 45.

94 See African Commission on Human and Peoples' Rights $v$ Republic of Kenya, App 6/2012, Judgment of 27 May 2017 para 53 and paras 58-61. 
Furthermore, the pleadings and submissions to the African Court (although not the hearings) are covered by principles of confidentiality $^{95}$ and, therefore, despite it being the culmination of a decision by the African Commission, the case then enters into a further closed procedure whereby information on any measures taken by the state is hidden from public view until any hearing and subsequent judgment by the Court.

\subsection{Requests by the state for technical assistance on how to interpret the judgment or decision}

There is some merit in the argument by some states that they were not clear on what precisely they were meant to do to implement the decision. For example, a generic 'take the necessary measures to bring in line with the African Charter and international human rights law' arguably is more nebulous than, say, the more specific recommendation that an individual victim is paid a certain amount of compensation. Leaving aside valid comments that a state with the necessary good-will certainly may find the appropriate manner in which to respond to the vaguest of recommendations, the question arises as to whether any requests from the state to the treaty body for further clarity and assistance in interpreting the decision themselves should be made public. The African Commission has not published any policy on what its response would be to such requests but the project found that there was a willingness, in some instances but not necessarily all, to engage with states post-decision to assist them in clarifying what action they should take to implement the decision. ${ }^{96}$

However, the extent to which states have made such requests to the African Commission is not evident. The project noted, through additional judgments of the African Court, that states have asked this judicial body for clarification on how to implement its judgments and reparations. ${ }^{97}$ While the trend is towards greater specificity in the recommendations and, therefore, the need may become less, the project found that states often say they want to be able to maintain a relationship with the African Commission to enable them to discuss what action they need to adopt to implement the decision.

Again, there may be cogent reasons why the discussion around the measures to be taken by the state should remain confidential. For example, the issue may be one of particular political sensitivity and it may enable a more open discussion if this is done out of the glare of the media. For instance, the Department of Execution of the Committee of Ministers in the Council of Europe's discussions with the

95 Rules of Court, Rules 60(1) and 61(1). Re hearings, see Rule 43; art 10 of the Protocol.

96 Eg interview D13, 23 November 2017; interview D4, 27 June 2017. Rule 111 of the African Commission's 2010 Rules of Procedure deals with reviews of decisions on the merits.

97 See eg App 1/2017 - Interpretation of Judgment of 20 November 2015 - Alex Thomas v United Republic of Tanzania, Judgment, 28 September 2017. 
state are not public. Although a state's action plan is published, the meetings with the state exclude civil society organisations as well as the applicants.

\section{Conclusion and recommendations}

At present the African Commission has slipped into presuming that measures taken by the state to implement recommendations, the evidence presented by the complainants (or indeed other actors) on the extent to which it has done so and the Commission's own assessment fall within the communication procedure and, therefore, by default are confidential. Yet, article 59 neither requires this nor do the Rules of Procedure, and a blanket approach to confidentiality post-decision is not appropriate.

The publication and dissemination of the decision itself over which there can be no doubt, as the 2017 Dakar Seminar of the African Commission reiterated, ${ }^{98}$ can be assisted with a few, low or no-cost, tactics. The Commission's website should be kept up to date and the Commission could draw on the African Court's approach, namely, to include as a standard paragraph in each of its decisions the requirements that the state publish the decision in a national paper, on social media and maintain it there for a particular period of time and publish, certainly at the national level, the procedures and those responsible for implementing the decision, and the measures it has taken to implement the decision and to share these specifically with the victims.

There may be some merit in discussions on technical assistance, however these are achieved, being kept confidential, but the outcomes (as with action plans adopted by states in respect of implementation of European Court of Human Rights judgments) should be made public. Regardless of the approach taken it is crucial that the African Commission set out criteria on when it will hold hearings, adopt resolutions or refer the matter to the African Court. These criteria also should be made public if the Commission is to avoid the criticism of being perceived as doing nothing or taking an inconsistent or potentially biased approach.

The African Commission, unless it is not in the interests of the victim to do so, should make public any information it receives from the state as to the measures taken to implement the reparations. The Commission does not appear to have any clear benchmarks that assess whether implementation is satisfactory or not, made more challenging by the ambiguity of some of its recommendations. Hence, making any appraisal of the state's actions is complicated. Yet, what the Commission can do is simply publish the information it has received from the parties without making any assessment as to 
whether state measures are satisfactory or not. This information could be provided on its website under the activities of the Working Group on Communications and in its activity reports, in practice akin to the approach of the African Court.

The recommendations in this article are not to imply that any action taken by the African Commission will be sufficient to ensure the visibility of its decisions and the measures taken to implement them, neither should they detract from the principal responsibility of the state authorities to make the decisions available at the national level and ultimately implement the reparations contained therein. However, at the very least these actions by the African Commission could heighten awareness of its decisions, indicate that the Commission has not lost interest in what states are doing in response to them, thereby ultimately increasing the likelihood that victims will receive justice. 